\title{
INTERCROPPING OF SOME ORNAMENTAL PLANTS IN CORN FIELD TO REDUCE SESAMIA CRETICA LED. INFESTATION
}

\author{
YACOUB, SH.S. ${ }^{1}$, AMANY S. EL-HEFNY ${ }^{1}$ AND \\ RASHA A. EL-HOSARY ${ }^{2}$
}

1. Plant Protection Research Institute, ARC, Dokki, Giza

2. Fac. of Agric., Benha University

(Manuscript received 15 October, 2010)

\begin{abstract}
Four ornamental plants Lantana salvifolia, Lantana (Verbeneceae), Geranium columbinam Pigeon's foot and Geranium robertianum Herb Robert (Geraniaceae) were intercropped with maize plants during early summer seasons plantation mid of April 2009 \& 2010 using two nursery methods (alternative hills alternative rows), aiming to study the effect of essential volatile oils scattered around maize plants against Sesamia cretica Led..

Results demonstrated that the nursery of Lantana and Sweat basil had the highest effect during the two seasons on number and vital of egg-masses and subsequently on number of larvae, number of plants containing perforated leaves and dead hearts. Also, the effect on dry ears weight was estimated. Generally, intercropping using the alternative hills was the best method of nursing. While nursery of Pigeon's foot ranked the third in this respect. However, nursery of Herb Robert was the least among all the ornamental plants used during the two seasons.
\end{abstract}

\section{INTRODUCTION}

Maize is one of the most important grain crop in Egypt. The pink stem borer, S. cretica Led. is one of the main corn stem borers in Egypt. The female moths prefer laying most of eggs on plants about 20 to 30 days after plantation. As the infested seedlings are dead heart and rotten in the same stage, consequently causing a great reduction in the yield, Abul-Nasr et al., (1968) and Awadallah (1974).

Most of the available literature demonstrated a great reduction in infestation rates and population density of insects attacking field crops when planted in mixed culture (Ezueh and Taylor, 1984). Mixed cropping systems are considered one of the agricultural methods employed in many parts of the world in order to increase the final 
income of the farmers Hards et al. 1983, Ali et al., 1993 Sharaf El Din et al., 1993 and Ali et al., 1995). Cultivation of sorghum, maize and cowpea in polyculture reduced insect populations significantly in comparison with monoculture (Dissemord and Hendrof, 1990). Tantawi et al., (1992) mentioned that when sugarcane was grown alone, $16.6 \%$ of the plants showed dead hearts due to $S$. cretica infestations when intercropped with onion in which the attack reduced to $5.8 \%$. While, growing garlic with sugarcane reduced the infestation with Chilo agamemnon but had no influence on S. cretica.

Awadallah et al., (1993) mentioned that planting corn into onion fields before onion irrigation was useful since $S$. cretica infestation was greatly reduced to none harmful levels also, the corn yield / unit area increased significantly when corn was planted alone.

All nursery of ornamental plants which were used in the present experimental study contained volatile oils so, this study aimed to assay the efficacy of these nursery as a repellent against $S$. cretica, and their effect on the subsequently yield. Histopathological studies were also carried out to insure the efficiency.

\section{MATERIALS AND METHODS}

\section{Field experiments}

Field experiments were conducted at the Experimental Farm of Agriculture Faculty of Moshtohor, Qualubiya Governorate throughout 2009 \& 2010 early maize summer seasons. In each year, an area of about half feddan was chosen to be cultivated with maize variety Giza 2 . The area was divided into plots in which sowing took place on April $15^{\text {th }}$ for both years. Also four nursery plants Lantana salvifolia, Lantana (Verbeneceae), Geranium columbinam Pigeon's foot and Geranium robertianum Herb Robert (Geraniaceae) were sown on $14^{\text {th }}$ April $2009 \& 2010$.

Intercropping system in this investigation depended on repellency effect due to odorous ornamental plants against $S$. cretica moths. Application of intercropping took place by using two methods: the first one was planting the ornamental plants in rows alternated (AR) with maize rows while the second was alternating hills (AH). The borders rows were planted by maize plants. Also, Diazinox granules $5 \%$ (approximately $2 \mathrm{gm}$ ) and single planted of corn were used as control.

The effect of odorous ornamental plants on S. cretica egg-masses and larvae were estimeted / 20 plants / plot. Perforated leaves and dead hearts cases were also estimated per 50 plants / plots after 40 days from sowing. At harvest time (about 120 days from sowing date) ears were weighed and adjusted to find out the yield (ardab / feddan). The percentage of reduction was calculate by following: 
$\%$ Reduction of infestation $=[(\mathrm{C}-\mathrm{T}) / \mathrm{C}] \times 100$

Where $\mathrm{C}:$ mean number of infestation symptoms in the check

$\mathrm{T}:$ mean number of infestation symptoms in the intercropping plants.

Analysis of variance (F Test) and least significant differences LSD (Snedecor and Cochran, 1980) were used for differentiating among treatments.

\section{RESULTS AND DISCUSSION}

\section{Effect of intercropping of some ornamental plants}

\section{1 - On deposited egg-masses}

Data presented in Table (1), showed the mean counts of the two seasons 2009 and 2010, in which all treatments caused significant reductions in the number of S. cretica egg-masses in either alternative hills or alternative rows. Probably, There was harmony in volatile oils' distribution in alternative hills $(\mathrm{AH})$ method which aid to have suitable odor surrounding the plants and subsequently effective repellency to $S$. cretica. The highest efficacy was due to sowing sweat basil nursery representing $96.6 \%-89.7$ and $93.8 \%-89.7 \%$ for $A H$ and AR in 2009 and 2010, respectively. While, sowing lantana nursery caused $93.8 \%-96.6$ and $93.8 \%-96.6 \%$ for $\mathrm{AH}$ and AR in 2009 and 2010, respectively.

Pigeons' foot and herb Robert nursery occupied the second and third rank in 2009 and 2010 seasons. Diazinox caused the least effect on S. cretica egg-masses recording $53.1 \%$ and $62.1 \%$ reduction in 2009 and 2010 for AH and AR methods, respectively.

\section{2 - On number of larvae}

The untreated maize plants harboured, significantly, the highest $S$. cretica larval counts in both seasons (58 and 49 larvae / 20 plants), respectively. Sowing nursery of Lantana achieved the highest reduction than control in both seasons by the two nursery method either AH or AR (93.1 \& 94.8\% and 98 \& $96 \%$ reduction than control, respectively). Followed by sweat basil nursery in 2009 the reduction was 91.4\% for methods of nursery. While in 2010 season pigeons' foot (AR) caused $91.8 \%$ reduction than control followed with sweat basil nursery which achieved $89.9 \%$ (5 larvae / 20 plants). Sowing herb Robert nursery had an intermediate efficiency being $72.4 \%$ reduction than control in 2009 for AH and AR nursery methods, respectively, showing $71.4 \& 75.5 \%$ reduction than control in 2010 season for $\mathrm{AH}$ and AR nursery methods, respectively. On the contrary, Diazinox was the least effective on larvae being 15 larvae / 20 plants representing 65.3 and $53.1 \%$ reduction than control, respectively, (Table, 1$)$. 


\section{3 - On number of perforated leaves}

All different nurseries caused high significant differences for all infestation symptoms of S. cretica Led. throughout the two studying seasons 2009 and 2010 . The highest average counts of the $1^{\text {st }}$ infestation - plants containing perforated leaves was recorded in untreated plants being 18 and 15 / 50 plants in 2009 and 2010, respectively. While, Lantana nursey sowed by the two different nursering methods were 2 and 2 plants containing perforated leaves / 50 plants, showing 86.7 and 80\% reduction than control in 2009 season. Also in 2010 season it caused 2 and 3 plants containing perforated leaves / 50 plants for $A H$ and $A R$, respectively. While plots containing sweat basil nursery had intermediate effect $80 \& 66.7 \%$ and $88.9 \& 83.3 \%$ reduction than control. For AH and AR, pigeon's foot it gave $60 \& 66.7 \%$ and $72.2 \&$ 93.3\% reduction than control and finally, herb Robert as $64.7 \& 33.3 \%$ and $66.7 \&$ 88.3\% reduction than control for the two seasons 2009 and 2010, respectively.

The least effective treatments was that of Diazinox which caused 33.3 and $38.9 \%$ reduction than control in 2009 and 2010, respectively, Table (1).

\section{4 - On number of dead heated cases}

Lantana nursery with the two different methods AH and AR appeared to be the best of all according to the dead hearted plants achieving throughout the 2009 and 2010 seasons being $1 \& 2$ dead hearted cases / 50 plants as $92.3 \& 84.6 \%$ and $93.3 \& 86.7 \%$ reduction than control, respectively.

On the other hand, Diazinox induced 38.5 and 33.3\% reduction than control in 2009 and 2010, respectively. The intermediate effect in 2009 for AH and AR and 2010 for $\mathrm{AH}$ and AR seasons were sweat basil nursery ( $84.6 \& 61.5$ and $80 \& 73.3 \%)$, pigeons' foot ( 60 \& 66.7 and $73.3 \& 86.7 \%$ ) and herb Robert (46.7 \& 33.3 and $80 \& 80 \%$ ) reduction than control, respectively.

The above mentioned results revealed that lantana and sweat basil nurseries showed high efficacy against $S$. cretica in which there were significant reduction in number of deposited eggs and subsequently number of larvae, plants containing either perforated leaves or dead hearted cases besides acceptable weight for dry ears as yield.

\section{5 - Calculated ears' weight yield / feddan}

All nurseries caused high significant increase in maize ears yield. Lantana nursery plants which were sown by alternative hills $(A H)$ or rows (AR) with maize plants caused the highest weight of ears in the first maize early summer season 2009, (29.4 and 28 ardab / feddan,) indicating 97.3 and $87.8 \%$ increase than control, respectively. Followed by nursery of sweat basil with (AH) and (AR) as 27.6 and 26.9 indicating 85.2 and $80.5 \%$ increase than control, respectively, Table (1). While, in the 
second early maize summer season 2010, sweat basil nursery caused the heaviest weight of ears by the two nursery methods, AH and AR (28 and 26.2 ardab / feddan, representing 87.9 and $75.8 \%$ increase than control, respectively). Nursery of lantana by $(\mathrm{AH})$ and (AR) nursery methods came next causing 67 and $57.7 \%$ increase than control, respectively.

The remaining nurseries in two maize early summer seasons 2009 and 2010 could be arranged descendingly according to the increase rate of than control - which achieved 14.9 ardab / feddan - by the two different nursery methods (AH) and (AR) as, pigeons' foot nursery being ( $53-41.6 \%)$ and $45.6-45.6 \%)$ increase than control in 2009 and 2010, respectively. Followed by herb robbert nursering being (45.6 $36.9 \%)$ and $(36.9-41.6 \%)$ increase than control in two seasons, respectively. On the contrary, Diazinox realized 34.2 and 36.9\% increase than control in 2009 and 2010, respectively, Table (1).

The obtained results are in harmony with Tantawy et al., (1992) mentioned that when sugarcane was grown alone, $16.6 \%$ of the plants showed dead hearts cases due to $S$. cretica infestation while in case of intercropping with onion the infestation was reduced to 5.8\%. Also Awadallah et al. (1993) recorded that planting onion fields before onion last irrigation was useful since $S$. cretica infestation was greatly reduced to non harmful levels, as well as the onion yield was not affected. The corn yield / unit area significantly increased in comparison with that cultivated alone. In 1996, Shalaby studied the effect of planting onion bulbs in maize fields on the degree of $S$. cretica infestation in which the author found that the highest mean number of egg-masses was 8.8 / 100 maize plants were laid in case of intercropping with maize plants. 


\section{REFERENCES}

1. Abul-Nasr, S.E., A.K.M. El-Nohal and S.K. Shahoudah. 1968. Some biological aspects of the corn stem borer, Sesamia cretica Led. Bull. Ent. Soc. Egypt, 52: 429 $-444$.

2. Ali. M.A., A.M. Tantawy, A.I. Shadeen and F. I. Ali. 1993. Effect of intercropping maize soybean systems on population density of soybean major pests. Al-Azahr . J. Agric. Res., 18: $21-49$.

3. Ali, M.A., A.S. El-khouly, I.L. Ibrahim and S.A. Naga. 1995. Effect of maize and cowpea intercropping on rate of aphid infestation grain yield, lond equivalent ratios and net income in maize / cowpea intercropping systems, Bull. Ent. Soc. Egypt, 73: $167-175$.

4. Awadallah, W.H. 1974. Biological studies on corn borers in Egypt, Ph.D. Thesis Fac. Of Agric. Ain Shams Univ., 176 pp.

5. Awadallah, W.H., A.F. Lutfallah, M.R. Sherif and M.H. Henna-Allah. 1993. Infestation of corn with onion to avoid infestation with the corn stem borer Sesamia cretica Led. In Egypt. J. Agric. Res. 71(3): 731 - 737.

6. Dissemond, A. and Handrof. 1990. Influence of sorghum / maize / cowpea intercropping on the insect suitable at Mbita / Kenya. Z. Ang. Ent. 129: 151 - 155.

7. Ezueh, M.I. AND A.T. Taylor. 1984. Effect of time of intercropping with maize on cowpeas susceptibility to three major pests. Trops. Agric. 61(2): $82-86$.

8. Hards, M. G., V. P. Bhagwat, B.K. Sharnagat. 1983. Influence of associated cropping system in incidence of sorghum pest complex collage of Agriculture Nagpur Magazine, 51 - 52: $19-27$.

9. Shalaby, G.A.E.M. 1996. Studies on certain maize pests in Kafr El-Sheikh Governorate. M. Sc. Thesis, Fac. of Agric., Zagazig Univ.

10. Sharaf, El-Din, A.A.A., I.I. Ismail, M.A.Ali and M.Y. Hashem. 1993. Effect of intercropping systems and planting methods on the population of onion pests. Bull. Ent. Soc. Egypt, 71: $139-152$.

11. Snedecor, G.W. and W.G. Cochran, 1980. Statistical methods $7^{\text {th }}$ edition, lowa State University Press. Ames, lowa.

12. Tantawi, M. A., F. Hayar, A.H. Shadeen and K.K. Mohamed. 1992. Preliminary studies of the effect of traditional intercropping systems in sugar cane fields on sugar cane borer Sesamia cretica Led. And Chilo agamemnon Bles. Infestation. Egypt. J. Agric. Res. 70(2): 527 - 532. 


\section{تحميل بعض نباتات الزينة فى حقول الـــرة الثـــاميـة لتقليل الاصابة

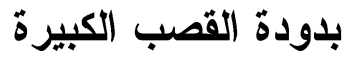

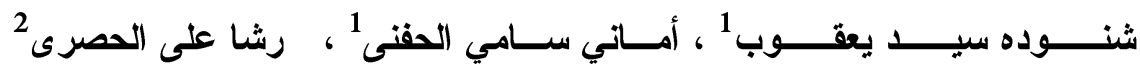

$$
\begin{aligned}
& \text { ا . . معزة بحوث وقـاية النباتات - مركز البـــوث الززراعيـة - الدقى }
\end{aligned}
$$

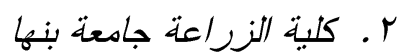

تمت دراسة تحميل أربع أنو اع مختلفة من النباتات الزينة وهى شتلات نباتات الريحان،

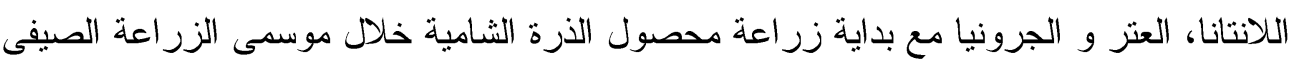

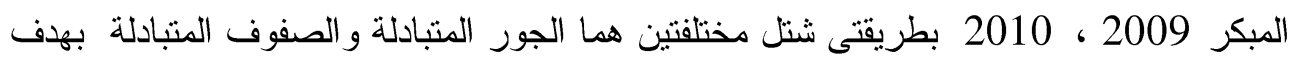

دراسة تأثير الزيوت العطرية الطاردة المنتشرة حول النباتات لدكافحة دودة القصب الكبيرة.

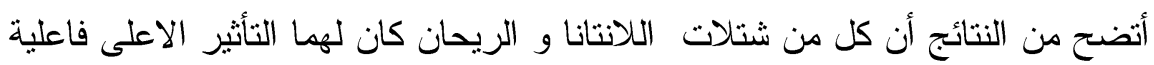

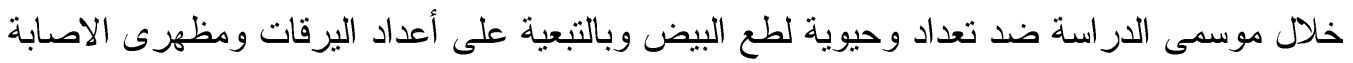

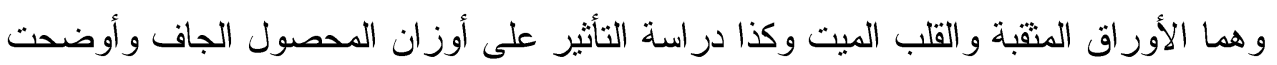

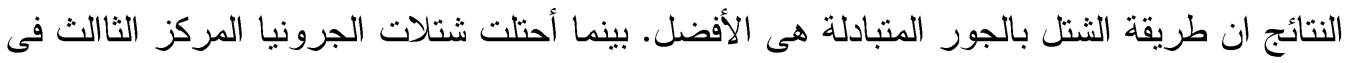
الثأثير كما كانت شتلات العتر أقل الانواع تأثير العى دودة القصب الكبيرة خلال موسمى الزئل التراعة. 